\title{
STRATEGI KETIDAKSANTUNAN POSITIF DALAM ACARA TALKSHOW BROWNIS TRANS TV
}

\author{
Bias Asmoroningtyas \\ Universitas Sebelas Maret
}

\begin{abstract}
Abstrak
Penelitian ini bertujuan untuk mendeskripsikan strategi ketidaksantunan positif dalam acara talkshow Brownis Trans TV. Pendekatan yang digunakan pada penelitian ini ialah pendekatan pragmatik. Data penelitian ini berupa tuturan pembawa acara dan bintang tamu yang mengandung strategi ketidaksantunan positif dalam acara talkshow Brownis Trans TV. Sumber data penelitian berasal dari dua belas video acara talkshow Brownis Trans TV yang ditayangkan pada bulan Agustus 2019. Metode pengumpulan data yang digunakan adalah metode simak dengan teknik unduh. Analisis data menggunakan metode analisis kontekstual. Hasil penelitian menunjukkan bahwa terdapat tujuh substrategi dari strategi ketidaksantunan positif yang ditemukan dalam acara talkshow Brownis Trans TV, yaitu (i) mengabaikan orang lain, (ii) mengecualikan, (iii) menunjukkan rasa ketidaktertarikan, (iv) menggunakan penanda identitas yang tidak tepat, (v) memilih topik sensitif, (vi) penggunaan umpatan/kata-kata kasar, dan (vii) sumpah serapah. Substrategi yang paling sering diterapkan dalam acara talkshow Brownis Trans TV ialah substrategi mengabaikan orang lain. Hubungan sosial antara penutur dan mitra tutur yang akrab menjadi faktor yang dominan memengaruhi munculnya strategi ketidaksantunan positif.
\end{abstract}

Kata-kata kunci: ketidaksantunan, strategi, Brownis

\begin{abstract}
This research aims to describe the positive impoliteness strategy in Brownis talkshow Trans TV. The approach used in this research is pragmatic approach. Data of this research are master of ceremonies and guest stars's utterances that contain positive impoliteness strategy in the Brownis talkshow Trans TV. Source of the data come from twelve videos of the Brownis talkshow Trans TV that aired in August 2019. Data collection method used referring method with the download technique. Data analysis used contextual analysis method. The results show that there are seven sub-strategies of positive impoliteness strategy that found in Brownis talkshow Trans TV, namely (i) ignoring others, (ii) excluding others, (iii) showing disinterested, (iv) using inappropriate identity markers, (v) selecting sensitive topic, (vi) using abusive words, and (vii) expletives. Substrategy of positive impoliteness that frequently used in Brownis talkshow Trans TV is ignoring others sub-strategy. Closeness social distance between speaker and hearer being dominant factor that influencing the appearance of positive impoliteness strategy.

Keywords: impoliteness, strategy, Brownis
\end{abstract}

\section{PENDAHULUAN}

Ketidaksantunan merupakan salah satu fenomena kebahasaan yang kini tidak lagi menjadi tabu di kalangan masyarakat. Sejak dulu, Indonesia terkenal dengan masyarakatnya yang berbudaya, ramah, dan santun, baik dalam segi sikap maupun tutur. Namun, seiring dengan berkembangnya zaman, identitas ramah dan santun tersebut lambat laun memudar. Munculnya fenomena 
ketidaksantunan berbahasa menjadi salah satu penanda bahwa kesantunan semakin sering diabaikan dan hal tersebut patut untuk diteliti lebih lanjut, mengingat santun atau tidaknya tuturan seseorang dapat menjadi tolok ukur kepribadian bangsa yang luhur.

Ketidaksantunan sendiri termasuk ke dalam salah satu kajian pragmatik yang masih terbilang baru. Berbeda dari kesantunan yang memang ditujukan untuk menjaga muka mitra tuturnya, ketidaksantunan adalah cara untuk menyerang dan merusak muka mitra tutur secara sengaja. Fenomena ketidaksantunan berbahasa ini dapat dengan mudah ditemukan dalam peristiwa tutur sehari-hari. Ketidaksantunan dapat muncul di mana saja, termasuk juga dalam tayangan-tayangan televisi, seperti sinetron, film, acara-acara reality show, talkshow, dan ajang pencarian bakat. Fenomena ketidaksantunan berbahasa dalam tayangan televisi juga masih belum banyak dikaji, sedangkan hal tersebut penting untuk dilakukan sebab tayangan televisi merupakan salah satu sarana hiburan yang hampir setiap hari dikonsumsi oleh masyarakat. Tayangan televisi dapat memengaruhi sikap serta cara bertutur penontonnya, baik secara langsung maupun tidak. Apabila banyak ditemukan fenomena ketidaksantunan dalam tayangan-tayangan tersebut, dikhawatirkan dapat berpengaruh terhadap cara bertutur masyarakat sehari-hari. Itulah mengapa fenomena ketidaksantunan berbahasa dalam acara televisi penting untuk dikaji.

Dewasa ini, tayangan televisi yang memiliki cukup banyak peminat ialah talkshow. Talkshow atau dapat disebut pula sebagai gelar wicara adalah salah satu jenis acara di televisi atau radio berupa diskusi atau perbincangan seorang atau sekelompok bintang tamu yang dipandu oleh pemandu gelar wicara mengenai suatu topik tertentu (Dwiheryana, 2015). Di Indonesia, terdapat beragam acara talkshow yang diminati oleh masyarakat, antara lain Rumpi (No Secret), Brownis, Bukan Empat Mata, E-Talkshow, Hitam Putih, dan Ini Talkshow. Acara-acara talkshow tersebut sebagian besar membahas tentang isu-isu yang sedang hangat diperbincangkan dan disajikan dengan bermacam-macam hiburan yang dipandu oleh pembawa acara terkenal. Dalam beberapa acara talkshow, tak jarang pula digunakan konsep humor untuk membuat penonton tertawa dan menarik minat masyarakat. Konsep humor tersebut dilakukan dengan cara mengejek kelemahan mitra tutur, menghina, atau mengujarkan kata-kata kasar sehingga memunculkan banyak fenomena ketidaksantunan.

Salah satu gelar wicara yang sering menyuguhkan konsep humor tersebut ialah Brownis. Nama Brownis merupakan singkatan dari Obrowlan Manis. Sebuah acara talkshow yang tayang setiap hari Senin hingga Jumat di Trans TV pada pukul 12.30 WIB yang dipandu oleh Ayu Ting-Ting, Ivan Gunawan, Ruben Onsu, dan Wendy Cagur. Acara ini ditayangkan pertama kali pada tahun 2017 dengan menampilkan obrolan ringan seputar isu artis dan isuisu lain yang sedang viral di kalangan masyarakat. Seperti acara gelar wicara pada umumnya, setiap hari Brownis menampilkan topik pembahasan yang 
berbeda dengan judul yang sangat panjang sebagai salah satu ciri khas talkshow tersebut. Brownis juga kerap menyuguhkan konsep humor yang dilakukan oleh pembawa acara dan para bintang tamu untuk menimbulkan kesan santai dan menghibur. Konsep humor yang disajikan tersebut pada akhirnya banyak memunculkan fenomena ketidaksantunan karena dilakukan dengan cara menyerang atau merusak muka mitra tutur. Contoh tuturan yang mengandung ketidaksantunan dapat ditemukan dalam penggalan dialog berikut.

(1) Konteks: Peristiwa tutur berlangsung pada acara talkshow Brownis Trans TV edisi 7 Agustus 2019 segmen 1, dengan melibatkan Ruben, Bekti, dan Igun sebagai peserta tutur. Dalam peristiwa tutur tersebut, Igun mengungkit kembali hutang yang pernah dimiliki oleh Bekti agar Bekti merasa berhutang budi dan menyesal karena tidak menghadiri acara konser Igun.

Ruben : Dia tuh pengen banget lo dateng karena Bekti, karena kan ada film lo ama dia badwalk, fan bareng-bareng dia...

Bekti : Iya gue tau...

Igun : Dua puluh empat karat, ada Babe Richard, lu juga dulu utang ama gue bertahun-tahun kaga lunas!

Bekti : (Tertawa, langsung menekap mulut Igun) Kaga usah diomongin! Nggak usah diomongin! Nggak usah diomongiiin!!! Elu denger-denger, pas di acara elu itu, lu ngomongin gue lu ya!

(2/TSB/SEG1/7-8-19/BOR)

Dalam penggalan dialog di atas, tuturan yang mengandung ketidaksantunan diujarkan oleh Igun. Tuturan yang diujarkan oleh Igun, yaitu Dua puluh empat karat, ada Babe Richard, lu juga dulu utang ama gue bertahun-tahun kaga lunas! termasuk ke dalam strategi ketidaksantunan. Strategi ketidaksantunan sering muncul seiring dengan ditampilkannya konsep humor oleh pembawa acara dan bintang tamu dalam acara talkshow Brownis Trans TV. Salah satu strategi ketidaksantunan yang diterapkan untuk memunculkan konsep humor pada acara tersebut adalah strategi ketidaksantunan positif. Strategi ketidaksantunan positif sering diujarkan oleh pembawa acara dan bintang tamu acara talkshow Brownis Trans TV dengan cara mengabaikan mitra tutur, mengecualikan, menunjukkan rasa ketidaktertarikan, dan lain sebagainya, untuk mendukung konsep humor yang disajikan dalam acara tersebut. Oleh sebab itu, data dalam penelitian ini dikaji menggunakan teori ketidaksantunan Jonathan Culpeper dengan berfokus pada strategi ketidaksantunan positif yang diujarkan oleh pembawa acara dan bintang tamu acara talkshow Brownis Trans TV. 
Sehubungan dengan permasalahan ini, terdapat enam kajian terdahulu yang membahas mengenai ketidaksantunan berbahasa dan memiliki relevansi dengan topik yang dikaji. Penelitian-penelitian tersebut di antaranya pernah dilakukan oleh Wijayanto (2014), Rahardi (2014), Hanif (2018), Kharisma (2018), Fhitri (2018), dan Utami (2019). Meskipun memiliki relevansi dengan penelitianpenelitian tersebut, penelitian ini juga memiliki perbedaan dengan kajian penelitian yang sudah ada. Pertama, penelitian ini berbeda dalam hal permasalahan yang dikaji, yaitu strategi ketidaksantunan positif. Kedua, penelitian ini memiliki perbedaan dalam hal sumber data, yaitu acara talkshow Brownis Trans TV. Acara tersebut belum pernah diteliti menggunakan kajian ketidaksantunan sebelumnya.

Berdasarkan pemaparan di atas, penelitian ini bertujuan untuk mendeskripsikan strategi ketidaksantunan positif dalam acara talkshow Brownis Trans TV. Penelitian ini diharapkan dapat memberi sumbangan ilmu pengetahuan perihal teori ketidaksantunan, khususnya mengenai strategi ketidaksantunan positif. Selain itu, penelitian ini juga diharapkan dapat bermanfaat bagi masyarakat umum sebagai pengetahuan baru tentang strategi ketidaksantunan positif dalam acara televisi, khususnya acara talkshow.

Konsep ketidaksantunan secara umum dibedakan berdasarkan tujuan penggunaan dan konteks yang melatarbelakanginya (Wijayanto, 2014: 116). Berdasarkan tujuan penggunaannya, ketidaksantunan didefinisikan sebagai "suatu kegiatan berbahasa yang ditujukan untuk merusak hubungan antarpersona atau menyerang muka mitra tutur dengan sengaja" (Archer, Bousfield, Culpeper, dan Limberg, dalam Wijayanto, 2014: 116). Culpeper (1996: 350) juga menegaskan bahwa ketidaksantunan merupakan "strategi yang digunakan untuk merusak hubungan sosial antarpenutur". Lebih lanjut, Culpeper (1996: 354) memaparkan tiga faktor yang melatarbelakangi adanya tindak ketidaksantunan dalam pengertian ini. Pertama, ketidakseimbangan power atau kekuatan sosial. Penutur dengan kekuatan sosial yang lebih dominan akan cenderung bertindak tidak santun kepada mitra tutur dengan kekuatan sosial yang lebih lemah. Kedua, keinginan penutur yang memang sengaja tidak ingin menjaga muka mitra tutur karena adanya konflik kepentingan. Ketiga, hubungan sosial penutur dan mitra tutur yang sangat akrab. Semakin akrab atau intim suatu hubungan, semakin besar pula peluang terjadinya ketidaksantunan.

Berdasarkan konteks yang melatarbelakangi, ketidaksantunan terjadi karena tuturan yang diujarkan tidak sesuai dengan konteks sosial-budaya yang melatarbelakanginya (Terkourafi dalam Wijayanto, 2014: 118). Lebih lanjut, Culpeper (2011: 23) mendefinisikannya sebagai sikap negatif terhadap perilaku tertentu yang terjadi dalam konteks tertentu. Perilaku dipandang negatif atau dianggap tidak sopan ketika mereka bertentangan dengan harapan, keinginan, dan/atau keyakinan seseorang dalam suatu kelompok atau organisasi tertentu. Berdasarkan pendapat ini, dapat dikatakan bahwa ketidaksantunan bergantung 
pada konteks sosial tertentu, bukan di dalam ujaran tertentu atau penanda linguistik tertentu (Wijayanto, 2014: 118).

Ketidaksantunan memiliki lima strategi yang berlawanan dengan teori kesantunan Brown dan Levinson dalam hal orientasi muka. Jika strategi kesantunan merupakan cara untuk menjaga muka, strategi ketidaksantunan adalah cara untuk menyerang muka. Kelima strategi ketidaksantunan tersebut adalah (i) ketidaksantunan secara langsung, (ii) ketidaksantunan positif, (iii) ketidaksantunan negatif, (iv) kesantunan semu atau sarkasme, dan (v) withhold politeness.

Strategi ketidaksantunan positif merupakan strategi yang digunakan untuk merusak keinginan muka positif mitra tutur, yaitu keinginan untuk dihormati, dihargai, diinginkan, dan dibutuhkan oleh orang lain. Strategi ketidaksantunan positif memiliki beberapa substrategi (Culpeper, 1996: 357-358), di antaranya (i) mengabaikan orang lain; (ii) mengecualikan; (iii) memisahkan diri dari yang lain; (iv) menunjukkan rasa ketidaktertarikan, ketidakpedulian, dan ketidaksimpatian; (v) menggunakan penanda identitas yang tidak tepat; (vi) menggunakan bahasa yang tidak jelas atau rahasia; (vii) mencari perselisihan dengan memilih topik yang sensitif; (viii) membuat orang lain merasa tidak nyaman; dan (ix) menggunakan kata-kata tabu, bahasa yang kasar, sumpah serapah, atau kata-kata yang tidak senonoh.

\section{METODE PENELITIAN}

Jenis penelitian ini adalah penelitian kualitatif yang bersifat deskriptif. Sebagaimana dikutip dari Bogdan dan Taylor (dalam Moleong, 2010: 4), penelitian ini termasuk dalam penelitian kualitatif karena prosedur penelitian yang dilakukan menghasilkan data deskriptif berupa kata-kata tertulis atau lisan dari orang-orang dan perilaku yang dapat diamati. Data deskriptif yang dihasilkan dalam penelitian ini adalah tuturan yang mengandung strategi ketidaksantunan positif dalam acara talkshow Brownis Trans TV yang kemudian ditranskripsi menjadi data tulis. Penelitian ini juga tergolong dalam penelitian kualitatif yang bersifat deskriptif karena data yang dikumpulkan adalah berupa tuturan yang mengandung strategi ketidaksantunan positif (berupa kata-kata dan bukan angka). Hal ini sejalan dengan pendapat Moleong (2010: 11), bahwa penelitian kualitatif akan menghasilkan data deskriptif, dengan data yang dikumpulkan adalah berupa kata-kata, gambar, dan bukan angka-angka.

Data penelitian ini berupa tuturan yang mengandung strategi ketidaksantunan positif dari pembawa acara dan bintang tamu acara talkshow Brownis Trans TV. Sumber data berasal dari dua belas video acara talkshow Brownis Trans TV yang ditayangkan pada bulan Agustus 2019. Untuk memudahkan transkripsi dan pencarian data, serta keterbatasan waktu untuk menyaksikan secara langsung acara tersebut di televisi, data tersebut diunduh dari situs Youtube TRANS TV Official. 
Metode pengumpulan data yang digunakan adalah metode simak karena cara yang digunakan untuk memperoleh data dilakukan dengan menyimak penggunaan bahasa (Mahsun, 2017: 91). Dalam penelitian ini, penyimakan dilakukan terhadap penggunaan bahasa lisan atau tuturan dalam acara talkshow Brownis Trans TV. Pada metode simak digunakan teknik simak bebas libat cakap. Artinya, peneliti tidak terlibat dalam peristiwa tutur dan sama sekali tidak berperan dalam menentukan pemunculan calon data. Selanjutnya, dilakukan teknik unduh. Pengumpulan data dilakukan dengan cara mengunduh video acara talkshow Brownis Trans TV dari situs Youtube TRANS TV Official. Teknik unduh ini akan mempermudah pada saat transkripsi dan penentuan data yang mengandung strategi ketidaksantunan positif.

Metode analisis data yang digunakan adalah metode analisis kontekstual. Menurut Rahardi (2009: 36), metode analisis kontekstual adalah "cara analisis yang diterapkan pada data dengan mendasarkan dan mengaitkan konteks". Konteks yang dimaksud adalah lingkungan di mana tuturan itu diujarkan. Dalam penelitian ini, konteks disampaikan terlebih dahulu dengan menyebutkan siapa saja peserta tutur yang terlibat, latar belakang, serta tujuan tuturan. Setelah konteks tutur disampaikan, hal yang selanjutnya dipaparkan adalah wujud tuturan dan analisis maksud yang sesuai dengan rumusan masalah.

\section{ANALISIS DAN PEMBAHASAN}

Berdasarkan teori ketidaksantunan Culpeper (1996), dalam acara talkshow Brownis Trans TV ditemukan tujuh substrategi ketidaksantunan positif, yaitu (i) mengabaikan orang lain; (ii) mengecualikan; (iii) menunjukkan rasa ketidaktertarikan; (iv) menggunakan penanda identitas yang tidak tepat; (v) memilih topik sensitif; (vi) penggunaan umpatan/kata-kata kasar; dan (vii) sumpah serapah. Ketujuh substrategi ketidaksantunan positif tersebut akan diuraikan sebagai berikut.

\section{Mengabaikan Orang Lain}

Salah satu substrategi ketidaksantunan positif yang ditemukan dalam penelitian ini adalah mengabaikan orang lain. Substrategi ini berarti penutur tidak menghiraukan mitra tutur saat berada di tempat yang sama, termasuk juga tidak memberikan kesempatan bicara dan tidak menghormati pendapat mitra tutur (Wijayanto, 2014: 117). Realisasi dari substrategi ini ditunjukkan dalam penggalan dialog berikut.

(2) Konteks: Peristiwa tutur berlangsung pada acara talkshow Brownis Trans TV edisi 7 Agustus 2019 segmen 1, dengan melibatkan Ruben, Igun, Bekti, dan Ayu sebagai peserta tutur. Dalam peristiwa tutur tersebut, Ruben dengan sengaja memotong komentar Igun sebagai juri dan langsung memberi jeda iklan. 


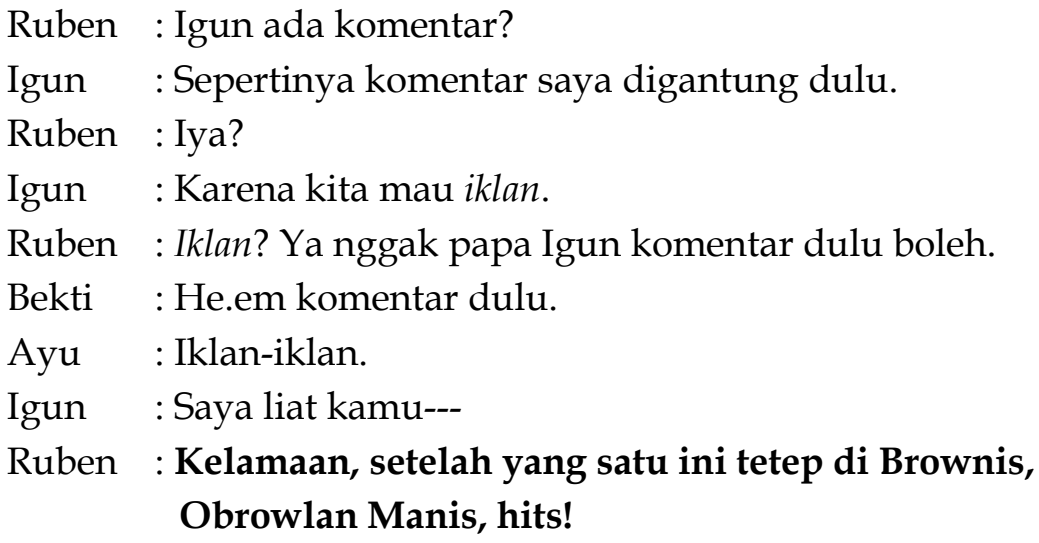

(4/TSB/SEG1/7-8-19/KP)

Pada dialog (2) di atas, terdapat realisasi strategi ketidaksantunan positif berupa mengabaikan orang lain yang diujarkan oleh Ruben sebagai penutur kepada Igun sebagai mitra tutur. Realisasi strategi ketidaksantunan tersebut dapat dilihat pada tuturan bercetak tebal, yaitu Kelamaan, setelah yang satu ini tetep di Brownis, Obrowlan Manis, hits! Pada tuturan ini, Ruben mengabaikan Igun yang berperan sebagai juri dengan sengaja memotong komentar Igun dan langsung memberi jeda iklan tanpa mempersilakan Igun untuk berkomentar lebih lanjut. Ruben sebagai host memotong komentar Igun dengan mengujarkan kata kelamaan yang lantas dilanjutkan dengan pemberian jeda iklan. Ruben sengaja mengabaikan komentar Igun dengan tidak memberinya kesempatan bicara, termasuk juga tidak menghormati pendapat Igun sebagai dewan juri. Padahal, sebelumnya Ruben dan Bekti sendiri mempersilakan Igun untuk berkomentar terlebih dulu sebelum jeda iklan. Faktor yang memengaruhi adanya tindak strategi ketidaksantunan ini ialah hubungan penutur dan mitra tutur yang sangat akrab. Ruben tampak sengaja menjahili Igun dengan mempersilakannya untuk memberi komentar terlebih dulu sebelum jeda iklan. Kemudian setelah Igun setuju untuk memberi komentar, Ruben dengan sengaja pula mengabaikan komentar Igun sebagai dewan juri dan memotong komentar tersebut sesuka hati. Hubungan pertemanan Ruben dan Igun yang cukup akrab membuat Ruben berani melakukan tindak ketidaksantunan tersebut.

\section{Mengecualikan}

Substrategi ketidaksantunan positif yang ditemukan selanjutnya, yaitu mengecualikan. Dalam substrategi ini, penutur sengaja membatasi diri agar mitra tutur tidak terlibat berkomunikasi dan mengecualikan mitra tutur dari suatu kegiatan (Wijayanto, 2014: 117). Realisasi dari substrategi ini ditunjukkan dalam penggalan dialog berikut.

(3) Konteks: Peristiwa tutur berlangsung pada acara talkshow Brownis Trans TV edisi 7 Agustus 2019 segmen 2, dengan melibatkan Ayu, Ruben, dan Elly sebagai peserta tutur. Dalam peristiwa tutur tersebut, Ruben dengan sengaja 
menyuruh kru Brownis untuk mematikan clip on Elly agar Elly tidak dapat berpartisipasi dalam pembicaraan.
Ayu : Ini mau nyanyi lagu apa nih sekarang?
Ruben : Lagu apa nyanyinya?
Ayu : Mau nyanyi lagu apa?
Elly : Tantang Barbie suruh nyanyi 3 lagu, tantang!
Ruben : Ssstt...eh peserta---eh matiin deh ini clip on-nya nih orang nih!

(Penonton tertawa)

(6/TSB/SEG2/7-8-19/KP)

Pada dialog (3) di atas, terdapat realisasi strategi ketidaksantunan positif berupa mengecualikan yang diujarkan oleh Ruben sebagai penutur kepada Elly sebagai mitra tutur. Realisasi strategi ketidaksantunan tersebut dapat dilihat pada tuturan bercetak tebal, yaitu Ssstt...eh peserta---eh matiin deh ini clip onnya nih orang nih!. Pada tuturan ini, Ruben sebagai host mengecualikan Elly yang pada saat itu berperan sebagai peserta dengan menyuruh kru Brownis untuk mematikan clip on yang dipakai oleh Elly agar Elly tidak dapat ikut berpartisipasi lagi dalam pembicaraan. Pada tuturan Ssstt...eh peserta---eh matiin deh ini clip on-nya nih orang nih!, Ruben juga secara jelas menunjukkan posisi Elly sebagai peserta acara Brownis Golden Voice sehingga Elly tidak pantas berpartisipasi dalam pembicaraan antara juri dan host. Apalagi jika dilihat dalam konteks tuturan di atas, Elly seolah menyuruh dewan juri untuk menantang peserta lain agar menyanyikan tiga lagu seperti dirinya. Ruben sengaja membatasi diri dengan cara menyuruh kru untuk mematikan clip on Elly, agar Elly sebagai mitra tutur tidak dapat terlibat berkomunikasi. Faktor yang memengaruhi adanya strategi ketidaksantunan ini ialah ketidakseimbangan kekuatan sosial. Ruben sebagai host memiliki kuasa yang lebih besar sehingga ia dapat melakukan tindak ketidaksantunan pada Elly yang saat itu hanya berperan sebagai peserta lomba.

\section{Menunjukkan Rasa Ketidaktertarikan}

Substrategi ketidaksantunan positif berikutnya ialah menunjukkan rasa ketidaktertarikan. Pada substrategi ini, penutur menunjukkan rasa ketidaktertarikannya terhadap mitra tutur. Ketidaktertarikan tersebut dapat berupa rasa tidak tertarik penutur terhadap topik pembicaraan yang sedang berlangsung maupun terhadap diri mitra tuturnya (Utami, 2019: 39). Realisasi dari substrategi ini ditunjukkan dalam penggalan dialog berikut.

(4) Konteks: Peristiwa tutur berlangsung pada acara talkshow Brownis Trans TV edisi 7 Agustus 2019 segmen 1, dengan melibatkan Ruben, Farhat, Bekti, dan Ayu sebagai peserta tutur. Dalam peristiwa tutur tersebut, Ayu menunjukkan 
rasa ketidaktertarikannya terhadap usul Bekti dengan secara langsung menolak usul tersebut.

Ruben : Mas akan nyanyi lagu lagi nggak, Mas?

Farhat : Ya, nanti kita buat lagu lagi.

Ruben : Kita buat lagu lagi, ya?

Bekti : Ini dong berempat Mas, bikinin berempat... ya?

Ruben : Apa?

Bekti : Berempat kek bikin lagunya...

Ayu : Enggak nggak usah deh.

(5/TSB/SEG1/7-8-19/KP)

Pada dialog (4) di atas, terdapat realisasi strategi ketidaksantunan positif berupa menunjukkan rasa ketidaktertarikan yang diujarkan oleh Ayu sebagai penutur kepada Bekti sebagai mitra tutur. Realisasi strategi ketidaksantunan tersebut dapat dilihat pada tuturan bercetak tebal, yaitu Enggak nggak usah deh. Pada tuturan ini, Ayu menunjukkan rasa ketidaktertarikannya terhadap usul Bekti untuk membuat lagu bersama dengan menolak usul tersebut secara langsung. Hal ini ditandai dengan penggunaan kata enggak dan nggak usah yang menandakan bahwa Ayu tidak setuju sekaligus tidak tertarik dengan usul Bekti untuk membuat lagu bersama Farhat Abbas. Hubungan sosial Ayu dan Bekti yang cukup akrab membuat Ayu berani mengujarkan tindak ketidaksantunan ini secara langsung. Selain itu, tindak ketidaksantunan ini juga dipengaruhi oleh keinginan penutur yang memang sengaja tidak ingin menjaga muka mitra tuturnya, yang mungkin disebabkan adanya konflik kepentingan. Ayu merasa tidak tertarik dan tidak ingin membuat lagu bersama dengan Farhat Abbas sehingga ia menolak dengan mengujarkan tindak ketidaksantunan tersebut secara langsung terhadap Bekti selaku pemberi usul.

\section{Menggunakan Penanda Identitas yang Tidak Tepat}

Substrategi ketidaksantunan positif lain yang ditemukan adalah menggunakan penanda identitas yang tidak tepat. Substrategi ini berarti penutur menggunakan sebutan atau julukan yang tidak pantas kepada mitra tutur atau memanggil mitra tuturnya dengan julukan yang bersifat menghina (Wijayanto, 2014: 117). Realisasi dari substrategi ini ditunjukkan dalam penggalan dialog berikut.

(5) Konteks: Peristiwa tutur berlangsung pada acara talkshow Brownis Trans TV edisi 22 Agustus 2019 segmen 2, dengan melibatkan Lydia, Ayu, Igun, dan Wendy sebagai peserta tutur. Dalam peristiwa tutur tersebut, Igun memanggil Wendy menggunakan julukan yang tidak pantas.

Lydia : Jadi Donat itu, kalo ditaruh di atas box itu biasanya kalo mau turun gitu dibilang Donat nggak boleh turun gitu, nanti dia naik lagi. 


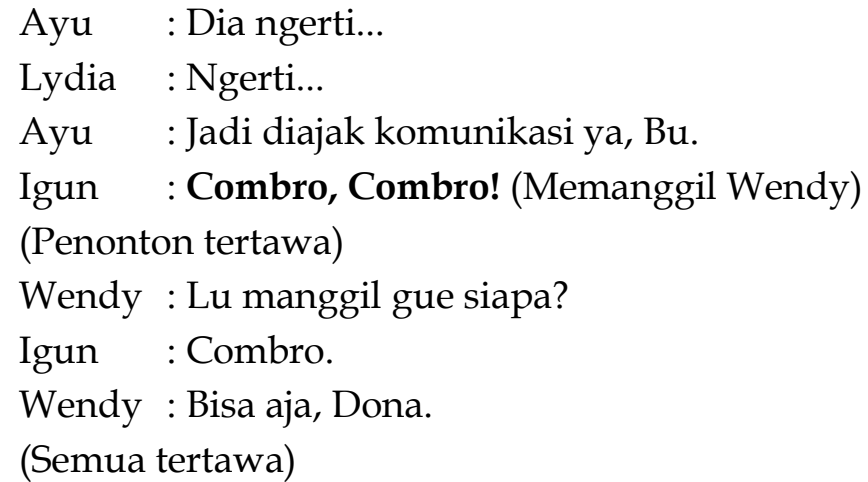

(1/TSB/SEG2/22-8-19/KP)

Pada dialog (5) di atas, terdapat realisasi strategi ketidaksantunan positif berupa menggunakan penanda identitas yang tidak tepat yang diujarkan oleh Igun sebagai penutur kepada Wendy sebagai mitra tutur. Realisasi strategi ketidaksantunan tersebut dapat dilihat pada tuturan bercetak tebal, yaitu Combro, Combro!. Pada tuturan ini, Igun memanggil Wendy dengan julukan yang tidak pantas atau menghina, seolah-olah Wendy adalah hewan peliharaan yang akan menurut bila dipanggil demikian oleh pemiliknya. Hal ini ditandai dengan penggunaan kata Combro untuk memanggil Wendy. Combro merupakan nama makanan khas Jawa Barat berupa gorengan berbentuk bulat dan berisi oncom. Igun sengaja memanggil Wendy dengan julukan tersebut, dengan konteks bahwa sebelumnya Ibu Lydia sebagai bintang tamu bercerita tentang ularnya yang bernama Donat, yang akan langsung patuh bila dipanggil dan disuruh. Igun kemudian mempraktikkan hal tersebut kepada Wendy dengan mengujarkan tuturan bercetak tebal, Combro, Combro!, seolah Wendy adalah hewan peliharaannya yang akan patuh bila dipanggil demikian. Faktor yang memengaruhi adanya tindak ketidaksantunan ini ialah hubungan sosial penutur dan mitra tutur yang sangat akrab. Igun dan Wendy memiliki hubungan pertemanan yang akrab sehingga Igun dapat menghina dan memanggil Wendy menggunakan julukan yang tidak pantas sesuka hati.

\section{Memilih Topik Sensitif}

Pada substrategi ketidaksantunan positif berupa memilih topik sensitif, penutur memilih atau membahas topik perbincangan yang sensitif untuk mencari atau menimbulkan perselisihan (Culpeper, 1996: 357). Realisasi dari substrategi ini ditunjukkan dalam penggalan dialog berikut.

(6) Konteks: Peristiwa tutur berlangsung pada acara talkshow Brownis Trans TV edisi 7 Agustus 2019 segmen 2, dengan melibatkan Ruben, Barbie, dan Bekti sebagai peserta tutur. Dalam peristiwa tutur tersebut, Ruben sengaja menyuruh Barbie Kumalasari untuk menyapa dan bersalaman dengan Farhat Abbas, padahal sebenarnya Barbie dan Farhat pernah dikabarkan saling terlibat perselisihan dalam kasus "Ikan Asin" hingga Barbie hampir menjadi tersangka. 


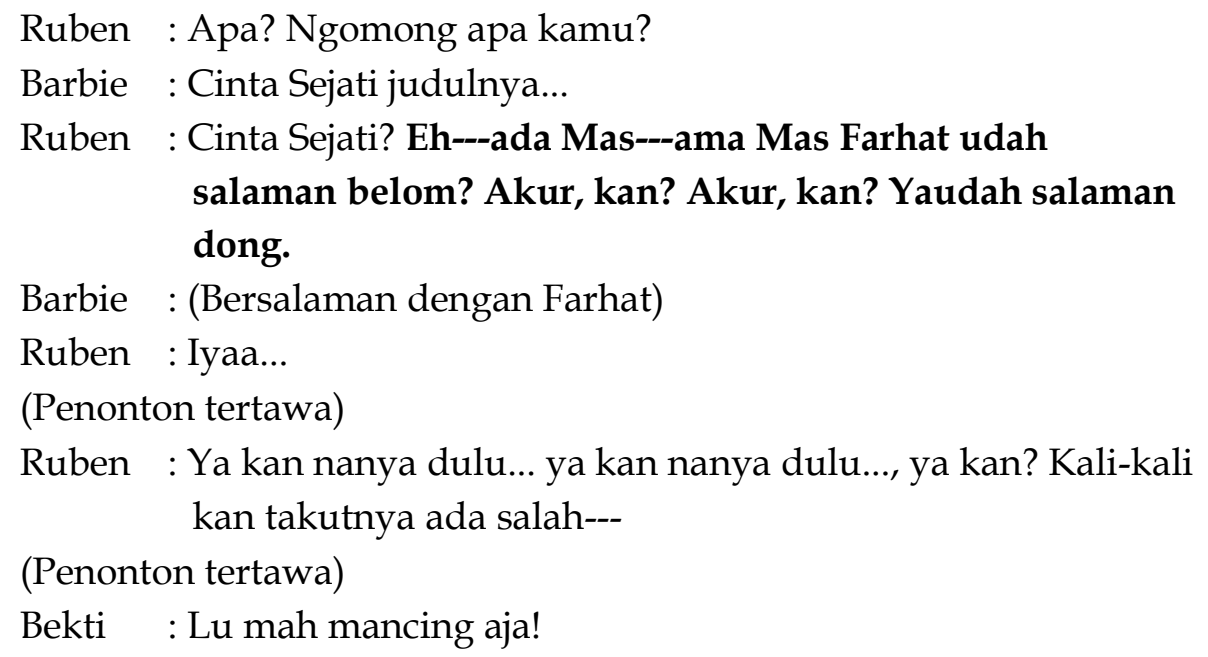

Pada dialog (6) di atas, terdapat realisasi strategi ketidaksantunan positif berupa memilih topik sensitif yang diujarkan oleh Ruben sebagai penutur kepada Barbie sebagai mitra tutur. Realisasi strategi ketidaksantunan tersebut dapat dilihat pada tuturan bercetak tebal, yaitu Eh---ada Mas---ama Mas Farhat udah salaman belom? Akur, kan? Akur, kan? Yaudah salaman dong. Pada tuturan ini, Ruben sebagai host mengungkit topik sensitif dengan menyuruh Barbie sebagai bintang tamu sekaligus peserta acara Brownis Golden Voice untuk bersalaman dengan Farhat Abbas yang sudah lebih dulu hadir sebagai bintang tamu dalam acara tersebut. Ruben memilih topik sensitif dengan pura-pura bertanya apakah hubungan Barbie dan Farhat baik-baik saja, kemudian menyuruh mereka untuk bersalaman. Padahal, Ruben jelas mengetahui bahwa Barbie Kumalasari dan Farhat Abbas pernah dikabarkan saling terlibat perselisihan dalam kasus "Ikan Asin" hingga hampir menyeret nama Barbie sebagai tersangka. Kasus "Ikan Asin" ini bermula ketika suami baru Barbie yang bernama Galih Ginanjar menyindir dan mengejek mantan istrinya (Fairuz A. Rafiq) di sebuah video Youtube dengan menyebut kata "Ikan Asin" yang dimaksudkan untuk mengolok organ intim Fairuz yang berbau seperti ikan asin. Galih kemudian dilaporkan atas tuduhan pembuatan konten yang dianggap melanggar kesusilaan serta pencemaran nama baik Fairuz. Barbie sebagai istri baru Galih disebut-sebut oleh Farhat Abbas, yang pada saat itu menjadi pengacara atas kasus tersebut, sebagai seseorang yang mengambil peran penting dalam pemberian nama "Ikan Asin" sehingga Farhat memaksa agar nama Barbie juga dimasukkan sebagai tersangka. Barbie dan Farhat lantas berseteru. Dalam acara Brownis ini, Ruben sebagai host seolah sengaja membuat mereka berdua saling menyapa dan bersalaman untuk mengungkit kembali perseteruan yang pernah terjadi di antara keduanya. Faktor yang memengaruhi tindak ketidaksantunan ini ialah keinginan penutur yang sengaja tidak ingin menjaga muka mitra tutur, yang mungkin disebabkan oleh adanya konflik kepentingan. Ruben sengaja memilih topik sensitif dengan bertanya apakah hubungan Barbie 
dan Farhat baik-baik saja hingga kemudian menyuruh mereka bersalaman untuk menyindir dan memancing kembali perselisihan yang sebelumnya pernah terjadi di antara mereka.

\section{Penggunaan Umpatan/Kata-Kata Kasar}

Salah satu substrategi ketidaksantunan positif lainnya ialah penggunaan umpatan/kata-kata kasar. Dalam substrategi ini, penutur menggunakan kata-kata yang tabu, bahasa yang kasar, atau kata-kata yang tidak senonoh kepada mitra tutur (Culpeper, 1996: 357). Realisasi dari substrategi ini ditunjukkan dalam penggalan dialog berikut.

(7) Konteks: Peristiwa tutur berlangsung pada acara talkshow Brownis Trans TV edisi 13 Agustus 2019 segmen 3, dengan melibatkan Ruben dan Nikita sebagai peserta tutur. Dalam peristiwa tutur tersebut, Nikita mengklarifikasi adanya tayangan yang menyebutkan bahwa dirinya melakukan 'panjat sosial' dengan Meldi. Ruben pun mengujarkan kata kasar saat berbicara dengan Nikita tentang penonton yang heboh sendiri saat Nikita melakukan klarifikasi tersebut.

\section{Ruben : Oke, nah. Kalo tadi, kalo tadi ya, kalo tadi katanya---dari eee... pada saat tayangan itu, Nikita enggan berkomentar, karena menurut Nikita--- \\ Nikita : Enggak, nanti kalo berkomentar nanti dibilangnya pansooos, padahal kan dari segi penampilan, ya kaan... bau-baunya udah beda. \\ Ruben : Lu---lu ngebacot penonton wuuuu.... pada---wuu pada--- ngerti nggak? Mereka tuh kan--}

Nikita : Iya ngerti, emang seneng keributan lu ya.

(Penonton bersorak)

$$
\text { (1/TSB/SEG3/13-8-19/KP) }
$$

Pada dialog (7) di atas, terdapat realisasi strategi ketidaksantunan positif berupa penggunaan umpatan/kata-kata kasar yang diujarkan oleh Ruben sebagai penutur kepada Nikita sebagai mitra tutur. Realisasi strategi ketidaksantunan tersebut dapat dilihat pada tuturan bercetak tebal, yaitu Lu---lu ngebacot penonton wuuuu.... pada---wuu pada---ngerti nggak? Mereka tuh kan--. Pada tuturan ini, Ruben mengujarkan kata kasar saat berbicara dengan Nikita, yaitu pada penggunaan kata bacot. Ruben mengatakan bahwa penonton heboh sendiri saat Nikita mengklarifikasi cuplikan video sebuah acara talkshow yang ditayangkan di layar Brownis. Dalam cuplikan video tersebut, Meldi (adik Dewi Persik) menuduh Nikita Mirzani mencari sensasi lewat perseteruan yang terjadi di antara mereka. Nikita pun mengklarifikasi tayangan yang menyebutkan bahwa dirinya mencari sensasi atau melakukan panjat sosial dengan Meldi tersebut. Pada tuturan bercetak tebal, Lu---lu ngebacot penonton wuuuu.... 
pada---wuu pada---ngerti nggak? Mereka tuh kan--, Ruben kemudian memberi tahu Nikita tentang penonton Brownis yang terus bersorak senang pada saat Nikita melakukan klarifikasi. Dalam tuturannya, Ruben mengujarkan kata kasar, yaitu ngebacot yang berarti berbicara. Kata bacot dalam Kamus Besar Bahasa Indonesia (daring) memiliki arti 'mulut' dan dikategorikan dalam ragam yang tidak sopan. Faktor yang memengaruhi tindak ketidaksantunan ini ialah hubungan sosial antara penutur dan mitra tutur yang akrab. Ruben dan Nikita memiliki hubungan pertemanan yang cukup dekat sehingga Ruben dapat dengan santai menuturkan kata kasar tersebut saat berbicara dengan Nikita.

\section{Sumpah Serapah}

Substrategi ketidaksantunan positif terakhir yang ditemukan, yakni sumpah serapah. Substrategi ini berarti penutur mengujarkan sumpah serapah kepada mitra tuturnya. Dalam Kamus Besar Bahasa Indonesia (daring), sumpah serapah diartikan sebagai 'kata-kata yang buruk, seperti maki-makian yang disertai kutukan, kutuk, tulah, dan lain sebagainya'. Realisasi dari substrategi ini ditunjukkan dalam penggalan dialog berikut.

(8) Konteks: Peristiwa tutur berlangsung pada acara talkshow Brownis Trans TV edisi 13 Agustus 2019 segmen 3, dengan melibatkan Ruben, Wendy, Nikita, dan Ayu sebagai peserta tutur. Dalam peristiwa tutur tersebut, Ayu menyumpahi Ruben yang terus mengungkit tentang hutang kado yang belum Ayu berikan sejak tahun 2017.

Ruben : Ini 2019---kan yang lu kasih tuh kado 2017, ngerti nggak? (Penonton tertawa)

Ruben : Ini, 2018 belom! Nah ini udah 2019 lagi.

Wendy :Ssstt...! Lu jangan ingetin kado yang dua, 700 rebu belom diganti ampe sekarang.

(Penonton bersorak)

Ruben : Yak, terima kasih untuk sahabat aku, Nikita Mirzani.

Nikita : Yaa Allah... (Tertawa)

Ruben : Ada bintang tamu, tapi kita ada tayangan dulu, ya. Coba kita liat---

Ayu : Gila emang gila harta. Kependem lo ama kado lo, kependem lo ama kado lo, gue doain!

(2/TSB/SEG3/13-8-19/KP)

Pada dialog (8) di atas, terdapat realisasi strategi ketidaksantunan positif berupa sumpah serapah yang diujarkan oleh Ayu sebagai penutur kepada Ruben sebagai mitra tutur. Realisasi strategi ketidaksantunan tersebut dapat dilihat pada tuturan bercetak tebal, yaitu Gila emang gila harta. Kependem lo ama kado lo, kependem lo ama kado lo, gue doain! Pada tuturan ini, Ayu mengujarkan sumpah serapah kepada Ruben karena Ruben terus mengungkit 
tentang hutang kado ulang tahun yang belum sempat Ayu berikan. Ruben juga membanding-bandingkan Ayu dengan Nikita Mirzani yang telah terlebih dulu memberi Ruben kado, bahkan sebelum tanggal ulang tahun Ruben tiba. Ayu kesal karena Ruben terus membahas tentang hutang kado tersebut hingga akhirnya mendoakan Ruben untuk sesuatu yang buruk. Pada tuturan bercetak tebal, Gila emang gila harta. Kependem lo ama kado lo, kependem lo ama kado lo, gue doain! Ayu mendoakan Ruben agar terkubur oleh kado-kado yang ia minta dari banyak orang. Ayu mengujarkan doa yang buruk kepada Ruben dan hal tersebut sama artinya dengan mengutuk atau sumpah serapah agar Ruben tertimpa sesuatu yang buruk. Selain itu, Ayu juga menyebut Ruben sebagai seseorang yang gila harta. Tindak ketidaksantunan ini dipengaruhi oleh keinginan penutur yang memang sengaja tidak ingin menjaga muka mitra tuturnya. Ayu sudah kesal terhadap Ruben yang selalu mengungkit tentang hutang kado ulang tahun dan membandingkannya dengan orang lain sehingga Ayu menuturkan strategi ketidaksantunan berupa sumpah serapah tersebut.

Berdasarkan klasifikasi data yang telah dilakukan, terdapat tujuh substrategi ketidaksantunan positif yang ditemukan dalam acara talkshow Brownis Trans TV, yaitu (i) mengabaikan orang lain; (ii) mengecualikan; (iii) menunjukkan rasa ketidaktertarikan; (iv) menggunakan penanda identitas yang tidak tepat; (v) memilih topik sensitif; (vi) penggunaan umpatan/kata-kata kasar; dan (vii) sumpah serapah. Berikut tabulasi data strategi ketidaksantunan positif yang ditemukan dalam acara talkshow Brownis Trans TV.

Tabel 1

Realisasi Strategi Ketidaksantunan Positif

\begin{tabular}{llcc}
\hline \multicolumn{1}{c}{ Strategi } & \multicolumn{1}{c}{ Substrategi } & Jumlah & Persentase \\
\hline $\begin{array}{l}\text { Ketidaksantunan } \\
\text { Positif }\end{array}$ & $\begin{array}{l}\text { Mengabaikan orang } \\
\text { lain }\end{array}$ & 17 & $60,7 \%$ \\
\cline { 2 - 4 } & Mengecualikan & 2 & $7,1 \%$ \\
\cline { 2 - 4 } & $\begin{array}{l}\text { Menunjukkan } \\
\text { ketidaktertarikan }\end{array}$ & 3 & $10,7 \%$ \\
\hline $\begin{array}{l}\text { Penanda identitas } \\
\text { yang tidak tepat }\end{array}$ & 1 & $3,6 \%$ \\
\hline $\begin{array}{l}\text { Memilih topik sensitif } \\
\text { Penggunaan }\end{array}$ & 2 & $7,1 \%$ \\
\hline $\begin{array}{l}\text { umpatan/kata-kata } \\
\text { kasar }\end{array}$ & 1 & $3,6 \%$ \\
\hline Sumpah serapah & 2 & $7,1 \%$ \\
\hline Jumlah & $\mathbf{2 8}$ & $\mathbf{1 0 0 \%}$ \\
\hline
\end{tabular}

Berdasarkan Tabel 1, dapat diketahui bahwa dari tujuh substrategi ketidaksantunan positif yang ditemukan dalam acara talkshow Brownis Trans TV, 
mengabaikan orang lain menjadi substrategi yang paling banyak diterapkan, yaitu sebanyak tujuh belas data atau sebesar 60,7\%. Sementara itu, substrategi ketidaksantunan positif yang paling sedikit diterapkan ialah penanda identitas yang tidak tepat dan penggunaan umpatan/kata-kata kasar, yaitu sejumlah satu data atau sebesar 3,6\%.

Pada substrategi mengabaikan orang lain, faktor yang memengaruhi ialah hubungan antara penutur dan mitra tutur yang sangat akrab, begitu pula pada substrategi penanda identitas yang tidak tepat dan penggunaan umpatan/kata-kata kasar. Pada substrategi mengecualikan, faktor yang memengaruhi ialah adanya ketidakseimbangan power atau kekuatan sosial. Selanjutnya, pada substrategi memilih topik sensitif dan sumpah serapah, faktor yang memengaruhi adalah keinginan penutur yang memang sengaja tidak ingin menjaga muka mitra tuturnya. Terakhir, pada substrategi menunjukkan rasa ketidaktertarikan, faktor yang memengaruhi adalah hubungan sosial antarpenutur yang akrab dan keinginan penutur yang memang sengaja tidak ingin menjaga muka mitra tutur.

Penggunaan strategi ketidaksantunan positif dominan dilakukan oleh pembawa acara talkshow Brownis Trans TV. Dari kelima pembawa acara Brownis, Ayu dan Ruben menjadi pembawa acara yang paling banyak menuturkan strategi ketidaksantunan tersebut. Adanya strategi ketidaksantunan positif dalam acara talkshow Brownis Trans TV ditandai oleh beberapa hal, antara lain penanda kebahasaan dan konteks yang melatarbelakangi diujarkannya tuturan.

\section{SIMPULAN}

Simpulan penelitian ini menunjukkan bahwa penggunaan ketidaksantunan berbahasa dalam acara talkshow Brownis Trans TV ditujukan untuk memperkuat konsep humor yang disajikan agar acara tersebut dapat menarik minat masyarakat luas dan mendapat peringkat (rating) tinggi dalam kancah pertelevisian Indonesia. Adapun penggunaan strategi ketidaksantunan positif yang ditemukan dalam acara talkshow Brownis Trans TV meliputi tujuh substrategi, yaitu (i) mengabaikan orang lain; (ii) mengecualikan; (iii) menunjukkan rasa ketidaktertarikan; (iv) menggunakan penanda identitas yang tidak tepat; (v) memilih topik sensitif; (vi) penggunaan umpatan/kata-kata kasar; dan (vii) sumpah serapah. Substrategi ketidaksantunan positif yang paling banyak diterapkan ialah substrategi mengabaikan orang lain. Penggunaan strategi ketidaksantunan positif dominan dilakukan oleh pembawa acara talkshow Brownis Trans TV. Dari kelima pembawa acara Brownis, Ayu dan Ruben menjadi pembawa acara yang paling banyak menuturkan strategi ketidaksantunan tersebut. Faktor yang paling dominan memengaruhi munculnya strategi ketidaksantunan positif, yakni adanya hubungan sosial antara penutur dan mitra tutur yang sangat akrab. Adanya strategi ketidaksantunan positif dalam acara talkshow Brownis Trans TV ditandai oleh 
beberapa hal, antara lain penanda kebahasaan dan konteks yang melatarbelakangi diujarkannya tuturan.

\section{DAFTAR PUSTAKA}

Culpeper, J. (1996). Towards an Anatomy of Impoliteness. Journal of Pragmatics, 25, 349-367.

Culpeper, J. (2011). Impoliteness: Using Language to Cause Offence. New York: Cambridge University Press.

Dwiheryana, R. (2015). Apa Itu Talkshow. Diunduh dari https://www.kompasiana.com/santarosa/54f37009745513942b6c768e/apa -itu-talkshow.

Fhitri, W. dan Yalmiadi. (2018). Ketidaksantunan dalam Pesan Singkat Mahasiswa kepada Dosen. Jurnal Gramatika, 4, 241-261.

Hanif, A. (2018). Ketidaksantunan Tuturan Juri dalam Acara Master Chef Indonesia di RCTI (Sebuah Pendekatan Pragmatik). Skripsi. Surakarta: Universitas Sebelas Maret.

Kharisma, A. (2018). Ketidaksantunan Praktisi Hukum terhadap Saksi Ahli dalam Sidang Jessica Kumala Wongso. Skripsi. Surakarta: Universitas Sebelas Maret.

Mahsun. (2017). Metode Penelitian Bahasa: Tahapan, Strategi, Metode, dan Tekniknya. Depok: Rajawali Pers.

Moleong, L. J. (2010). Metodologi Penelitian Kualitatif (Edisi Revisi). Bandung: PT Remaja Rosdakarya.

Rahardi, R. K. (2009). Sosiopragmatik. Jakarta: Penerbit Erlangga.

Rahardi, R. K., Setyaningsih, Y., dan Dewi, R. P. (2014). Kata Fatis Penanda Ketidaksantunan Pragmatik dalam Ranah Keluarga. Adabiyyāt, 18, 149-175.

Utami, K. L. (2019). Strategi dan Fungsi Ketidaksantunan dalam Reality Show 86 di Net TV. Skripsi S-1 (Tidak dipublikasikan). Surakarta: Universitas Sebelas Maret.

Wijayanto, A. (2014). Ketidaksantunan Berbahasa: Penggunaan Bahasa Kekerasan di Sinetron Bertema Kehidupan Remaja. Prosiding. Surakarta: Universitas Muhammadiyah Surakarta.

https://kbbi.kemdikbud.go.id/. Diakses pada tanggal 14 Mei 2020, pukul 06.11 WIB. https://www.transtv.co.id/program/86/brownis. Diakses pada tanggal 28 Oktober 2019, pukul 09.12 WIB.

https://www.youtube.com/channel/UCIohHXwCEKxWCLvAguJ-GjA. Diakses pada tanggal 14 Mei 2020, pukul 06.09 WIB. 